\title{
Editorial
}

\section{Ciência, Tecnologia, Inovação e um ano de Pandemia no Brasil}

Neste mês de março de 2021, a pandemia provocada pelo vírus SARS-COV-2 completou oficialmente um ano no Brasil e ainda não há sinal de arrefecimento do ritmo de contágio ou da perda de vidas. Estamos, de fato, em uma segunda e mais forte onda. Já há, todavia, aspectos importantes a registrar, tanto com respeito aos óbvios pontos negativos quanto com relação a alguns positivos.

Desde o início dessa crise, estabeleceu-se uma inédita mobilização de profissionais de diferentes origens, formações e vinculações, tanto do governo quanto de instituições acadêmicas e empresas, com atividades paralelas das mais diversas. Esses profissionais estão trabalhando para projetar, testar e produzir equipamentos, medicamentos e vacinas; organizar, processar e publicar dados; propor e realizar testes para detecção de contágio; dar suporte às populações economicamente fragilizadas; criar e adaptar modelos matemáticos para realizar projeções; orientar e comunicar a situação ao público; produzir instrumentos de proteção para profissionais de saúde; e, inclusive, avaliar e publicar trabalhos científicos relacionados ao esforço de combate à pandemia. Trabalhos estes que estão sendo publicados, frequentemente, em edições especiais e aceleradas por meio de esforços concentrados das equipes editoriais das revistas, como está sendo feito também pela Cadernos de Prospecção.

Felizmente, diferente de um ano atrás, há hoje várias vacinas disponíveis e testadas, algumas com produção local, embora em ritmo ainda insuficiente e sob constante risco do aparecimento de variantes que as escapem. Além disso, dos países constantes do chamado BRICS, apenas o Brasil e a África do Sul não têm vacina própria aprovada e, apesar dos esforços de empresas, governos e instituições, ainda dependemos de acordos de fornecimento de insumos importados, tanto para vacinas quanto para testes.

O principal aspecto em que o Brasil decididamente não está apresentando boa performance é o da coordenação política e organização de consensos mínimos para o combate ao problema comum. Curiosamente, dos termos muito frequentemente repetidos em todo o complexo torvelinho de conflitos entre autoridades e lideranças, foi "a ciência" que aparentemente alcançou um status de disputa inédito em nosso país. No entanto, medidas recentes de poderes da República, em diferentes níveis, demonstram na prática o esquecimento de que, caso realmente se entenda que Ciência, Tecnologia e Inovação (CT\&I) é importante, tanto nesse desafio histórico quanto em outros que precisamos muito vencer, a CT\&I depende, como qualquer atividade humana, de meios materiais, de certa previsibilidade institucional e de suporte para ser executada com êxito, mais do que discursos.

A prospecção tecnológica emprega técnicas avançadas e dados minuciosos para avaliar tendências de comportamento de setores, atores e temas importantes. Algumas previsões, no entanto, são até fáceis de se fazer com base na experiência recente. Decisões anteriores de re- 
tardo e de abandono de investimentos estratégicos nos trouxeram a essa particular posição de dependência em vacinas, testes e insumos. Tal "economia de recursos" hoje nos custa muito caro, tanto em vidas como na própria atividade econômica. Repetir o mesmo erro e esperar bons resultados não parece ser sensato. De fato, era justamente isso que Einstein citava como definição de loucura.

Ao todo, esta edição da revista Cadernos de Prospecção reúne 23 artigos de 87 autores que representam 22 organizações brasileiras de 14 Unidades da Federação localizadas em quatro regiões do Brasil e no Distrito Federal.

Desejamos a todos uma excelente leitura!

Gesil Sampaio Amarante Segundo

Professor Titular da Universidade Estadual de Santa Cruz Presidente Interino do Parque Científico e Tecnológico do Sul da Bahia Presidente do Fórum Nacional de Gestores de Inovação e Transferência de Tecnologia (FORTEC) 